Bangladesh J. Sci. Res. 29(2): 123-131, 2016 (December)

\title{
INFLUENCE OF BRICK MANUFACTURING ON PHOSPHORUS AND SULFUR IN DIFFERENT AGRO-ECOLOGICAL SOILS OF BANGLADESH
}

\author{
Reshma Akter, Md. Jamal Uddin ${ }^{1}$, Md. Faruque Hossain ${ }^{2}$ and Zakia Parveen* \\ Department of Soil, Water and Environment, University of Dhaka, \\ Dhaka 1000, Bangladesh
}

\begin{abstract}
A study was carried out to evaluate the effects of brick manufacturing on phosphorus (P) and sulfur (S) concentrations in soil and plant collected from different distances of brick kilns in four AEZs of Bangladesh. Forty eight composite soil samples ( $0-15 \mathrm{~cm}$ depth) were collected from 48 points in 12 different sites at $0 \mathrm{~m}, 300 \mathrm{~m}, 800 \mathrm{~m}$ and $1500 \mathrm{~m}$ from brick kilns, where most (site 2 , site 3 , site 5 , site 6 , site 7 , site 9 and site 10 ) of the brick kilns used coal for brick burning purposes. Plant samples (rice straw and different vegetables) were also collected from the respective fields except $0 \mathrm{~m}$ distances. Significantly $(\mathrm{p} \leq 0.05)$ lower organic matter, cation exchange capacity, clay content and soil $\mathrm{pH}$ were found at $0 \mathrm{~m}$ distances compared to other distances. Highest concentration of total $\mathrm{P}$ in soil were recorded at $0 \mathrm{~m}$ distances and these concentrations decreased with increasing distances from the brick kilns in most of the sites; whereas available $\mathrm{P}$ is significantly lower at $0 \mathrm{~m}$ distances than that of other distances. Total and available concentration of $S$ in soil followed the trend $0 \mathrm{~m}>300 \mathrm{~m}>800 \mathrm{~m}>1500 \mathrm{~m}$. Maximum accumulation of $\mathrm{P}\left(69.15 \mathrm{mg} \mathrm{kg}^{-1}\right)$ and $\mathrm{S}(0.14 \%)$ in plant was found at $800 \mathrm{~m}$ away from the brick kiln.
\end{abstract}

Key words: Phosphorus, sulfur, concentration, accumulation, agro-ecological soils

\section{Introduction}

Bricks are essential basic materials used frequently in construction, a fundamental commodity for accomplishing various infrastructural projects for developing new urban areas. The productive agricultural land is the best material for brick making because of its clay and silt content. The irony of the situation is that the soil, which could have provided a large amount of agricultural production, in turn being used for raising man made cement mountains in the mega cities. Swelling urban population has necessitated vast lands for quarrying, to cater to the corresponding exaltation in demand for bricks and construction materials. Extensive areas quarried for clay and silt those are needed to mould the bricks.

Therefore, at present Bangladesh has about 6,000 authorized brickfields and numerous illegal ones (Bayron 2009, Sikder et al. 2016). This widespread existence of brick kilns is one of the main sources of air pollution in Bangladesh and prominent cause of this pollution is using coal and wood. Emissions from brick manufacturing include particulate matter (PM), PM less than or equal to 10 microns in aerodynamic diameter $\left(\mathrm{PM}_{10}\right)$, $\mathrm{PM}$ less than or equal to 2.5 microns in aerodynamic diameter $\left(\mathrm{PM}_{2.5}\right)$, sulfur dioxide, sulfur trioxide, nitrogen oxides, carbon monoxide,

*Author for correspondence: <zakiaparveen1@yahoo.ca>. ${ }^{1}$ University of Barisal, Barisal 8200, Bangladesh.

${ }^{2}$ American International University-Bangladesh, Kemal Ataturk Avenue, Banani, Dhaka 1213, Bangladesh. 
carbon dioxide, metals, total organic compounds (including methane, ethane, volatile organic compounds, and some hazardous air pollutants, hydrochloric acid, and fluoride compounds) (USEPA 1986).

Soils near brick kilns are relatively acidic in nature and brick kilns produce large amount of $\mathrm{SO}_{2}$ during the burning of coal and wood. This greenhouse gas lowers the $\mathrm{pH}$ of the adjacent soil when it is mixed up with water and produced $\mathrm{H}_{2} \mathrm{SO}_{4}$. Hence, acid rain is the regular phenomenon near the brick kilns area (Kabata and Pendias 1992, Sikder et al. 2015). Brick kilns also produce some gaseous phosphorus during hot burning (Rahman et al. 2015) and the maximum availability of the primary nutrient phosphorus and secondary nutrient sulphur is found in the $\mathrm{pH}$ ranges from 6.5 to 7.5 (Yaseen et al. 2015, Bisht and Neupane 2015) but at the low pH the P is fixed with Fe and $\mathrm{Al}$. So, the availability of these nutrients in soil depends on organic matter, $\mathrm{CEC}, \mathrm{pH}$ and soil texture which are changed due to brick making operations (Kabata-Pendias and Pendias. 2001). The changes of land and soil properties have a tillage impact on the quality and fertility status of soil. Fertility degradation has enormous impact on soil productivity and decreasing agricultural production drastically by reducing fertility levels of the soil. It decreases fertility status of the soil, and due to lack of essential nutrients, crops reported to be prone to many pests and diseases as well. To recover the production, farmers have been applying heavy doses of chemical fertilizers, which may have other harmful consequences. Thus, the objective of this study is to assess the effects of brick manufacturing on $\mathrm{P}$ and $\mathrm{S}$ content nearby brick kiln soils at different distances in four agro-ecological zones in Bangladesh.

\section{Materials and Methods}

On the basis of geographic positions four different AEZs such as, AEZ 12 (Low Ganges River Floodplain), AEZ 13 (Ganges Tidal Floodplain), AEZ 18 (Young Meghna Estuarine Floodplain) and AEZ 19 (Old Meghna Estuarine Floodplain) have been selected to conduct the research.

Soil samples were collected from the surrounding agricultural fields adjacent to the brick kilns in March, 2015. Four distances such as $0 \mathrm{~m}, 300 \mathrm{~m}, 800 \mathrm{~m}$ and $1500 \mathrm{~m}$ were identified based on the predicted brick kilns emission distances (Sikder et al. 20016). Zero meter distance indicates burnt soil and $300 \mathrm{~m}, 800 \mathrm{~m}$ and $1500 \mathrm{~m}$ indicate unburnt soil. Forty eight composite soil samples ( $0-15 \mathrm{~cm}$ depth) were collected from 48 points in 12 different sites at $0 \mathrm{~m}, 300 \mathrm{~m}, 800 \mathrm{~m}$ and $1500 \mathrm{~m}$ from brick kilns (Table 1).

Thirty six plant (rice straw and different vegetables) samples were also collected from the respective fields. About 10 to 20 plant samples were collected from each point by uprooting. Both composite soil and plant samples were air dried, then soil samples were ground and sieved through a $2 \mathrm{~mm}$ sieve and plant samples with a $0.2 \mathrm{~mm}$ sieve and stored for chemical analysis.

The soil $\mathrm{pH}$ was determined by glass electrode $\mathrm{pH}$ meter at a soil: water ratio of $1: 2.5$ as described by Jackson (1973). The organic carbon of the soil samples was determined by Walkley and Black's wet oxidation method as outlined by Jackson (1973). The organic matter content was

calculated by multiplying the content of organic carbon by Van Bemmelen's factor 1.73 (Piper 
1950). The cation exchange capacity of the soil samples was determined by extracting the soil with normal ammonium acetate (Chapman 1965).

Table 1. Brief description of sampling sites.

\begin{tabular}{llc}
\hline AEZ No. and names & Location (Union, Upazila, district) & $\begin{array}{c}\text { Sampling } \\
\text { sites }\end{array}$ \\
\hline 12. Low Ganges River Floodplain & Kutubpur, Kalkini, Madaripur & 1 \\
& Keshobnagar, Kotoyali, Faridpur & 2 \\
13. Ganges Tidal Floodplain & Purba Anrajhuri, Kaukhali, Pirojpur & 3 \\
& Jhalokathi, Jhalokathi, Jhalokathi & 4 \\
& Rana Pasa, Nolcity, Jhalokathi & 5 \\
& Angara, Dumki, Patuakhali & 6 \\
& Puiterpara, Bakergonj, Barisal & 7 \\
18. Young Meghna Estuarine Floodplain & Gangapur, Burhanuddin, Bhola & 8 \\
& Char Madras, Charfassion, Bhola & 9 \\
& Bhedaria, Bhola, Bhola & 10 \\
19. Old Meghna Estuarine Floodplain & Borakotha, Ujirpur, Barisal & 11 \\
& Baligram, Kalkini, Madaripur & 12 \\
\hline
\end{tabular}

After digestion of the soil samples with aqua-regia $\left(\mathrm{HCl}: \mathrm{HNO}_{3}=3: 1\right)$, the extract was used to determine the total sulphur content by turbidimetric method using spectrophotometer at $420 \mathrm{~nm}$ wavelength. The total phosphorus content of the samples were determined by colorimetric method using a spectrophotometer by developing yellow color with vanadomolybdate as described by Jackson (1962).

Available $\mathrm{S}$ was determined by turbidity of suspended barium sulphate using tween- 80 as stabilizer and the turbidity was measured by spectrophotometer at $420 \mathrm{~nm}$ wavelength (Jackson 1962). Soil available phosphorus was extracted by using the Bray and Kartz method for $\mathrm{pH}$ less than 7 and Olson method for $\mathrm{pH}$ greater than 7. The extract was analyzed colorimetrically following the blue color method using ascorbic acid by spectrophotometer at $880 \mathrm{~nm}$ wavelength (Jackson 1962).

Plant samples were digested with concentrated nitric acid and perchloric acid. After digestion of the samples the extract was used to determine the total $\mathrm{S}$ content by turbidimetric method and the total $\mathrm{P}$ was determined by colorimetric method.

The statistical analyses ANOVA and correlation were done using Stata software version 12.

\section{Results and Discussion}

Soil properties near brick kilns in selected four AEZs: The parent materials of sampling sites, selected for the research are medium high land to low land which suggested high amount of clay 
percentage (Table 2) and clay provide more surface area for accumulation of metal ions. According to sampling sites the highest clay was recorded at $1500 \mathrm{~m} \mathrm{(44.0 \% )} \mathrm{in} \mathrm{site} 4$ and lowest clay was recorded at $0 \mathrm{~m}(4.0 \%)$ in site 9 .

Soil $\mathrm{pH}$ is an important index of ecological condition of terrestrial environment (Yaseen et al. 2015). It affects the availability of nutrients to plants and the activity of soil microorganisms. In addition, soil can be used as a carrier of toxic substances such as heavy metals. The maximum availability of the primary nutrients like nitrogen, phosphorus, and potassium as well as secondary nutrients like sulphur, calcium, and magnesium are found in the $\mathrm{pH}$ ranges from 6.5 to 7.5 (Yaseen et al. 2015, Bisht and Neupane 2015). The pH provides a good indication of soil chemical nature where higher $\mathrm{pH}$ indication optimal range for plant growth but lower $\mathrm{pH}$ causes problems for normal growth of the plants (Yaseen et al. 2015). The $\mathrm{pH}$ values of the samples ranged from 4.95 to 7.70 in 12 sampling sites (Table 2). Results showed that the samples in the studied area were very strongly acidic, slightly acidic, neutral and slightly alkaline in nature. Organic carbon is an important parameter of soil that determines beneficial effects on soil quality. It improves soil structure, enhances aeration and water penetration, and increases water holding capacity and supplies nutrients for growth of plants. Organic carbon levels greater than $0.8 \%$ are rated as good quality of soil (Yaseen et al. 2015). Organic carbon of the soil in this study area ranges from 0.13 to $1.15 \%$ (Table 2). The highest OC content $(1.15 \%$ ) was found in soil at $1500 \mathrm{~m}$ (site 11) and lowest $0.13 \%$ at $0 \mathrm{~m}$ (site 9) (Table 2). Organic carbon level in soil samples near brick kiln was found poor reflecting the presence of high temperature close to brick kiln (Monga et al. 2012).

The maximum cation exchange capacity in soil was recorded $2.98 \mathrm{meq} / 100 \mathrm{~g}$ at $1500 \mathrm{~m}$ (site 11) and minimum CEC was observed $0.34 \mathrm{meq} / 100 \mathrm{~g}$ at $0 \mathrm{~m}$ (site 4 and site 7) (Table 2). The value of CEC varied at different distances from site to site in four AEZs.

Effects of brick making operations on status of phosphorus and sulfur in soil: It is apparent from the data in Fig. 1a that the highest concentration of total phosphorus in surface soil was recorded $0.14 \%$ at $0 \mathrm{~m}$ (site 4 ) and the lowest concentration of $\mathrm{P}$ was $0.04 \%$ at $1500 \mathrm{~m}$ (site 6 ). Concentration of total $\mathrm{P}$ decreased with the increasing distances from brick kilns and followed the order: $0 \mathrm{~m}>300 \mathrm{~m}>800 \mathrm{~m}>1500 \mathrm{~m}$. It is noticeable that at $0 \mathrm{~m}$ for site 4 and site 5 the total $\mathrm{P}$ concentration were significantly $(\mathrm{p} \leq 0.05)$ higher than other distances. Total $\mathrm{P}$ concentration showed positively and significant correlation with $\mathrm{CEC}, \mathrm{pH}$ and clay content (Table 3). The reverse trend was seen for available $\mathrm{P}$ (Fig 1b). The available P concentration was not high at $0 \mathrm{~m}$ distances compared to $300 \mathrm{~m}, 800 \mathrm{~m}$ and $1500 \mathrm{~m}$ from the brick kilns in most of the sites, reflects that low $\mathrm{pH}$ and high temperature reduce $\mathrm{P}$ availability. It is well known that at low $\mathrm{pH}, \mathrm{Al}$ and $\mathrm{Fe}$ form strong bond with phosphate and decrease the availability of phosphate at $0 \mathrm{~m}$ distances. Table 3 provides that soil available $\mathrm{P}$ concentration and soil $\mathrm{pH}$ were positively correlated. The standard level of $P$ for plant cultivation is $21.0 \mathrm{mg} \mathrm{kg}^{-1}$ (BARC 1997). Results showed that the available $\mathrm{P}$ at different distances in soil was below the standard level in most of the points. 


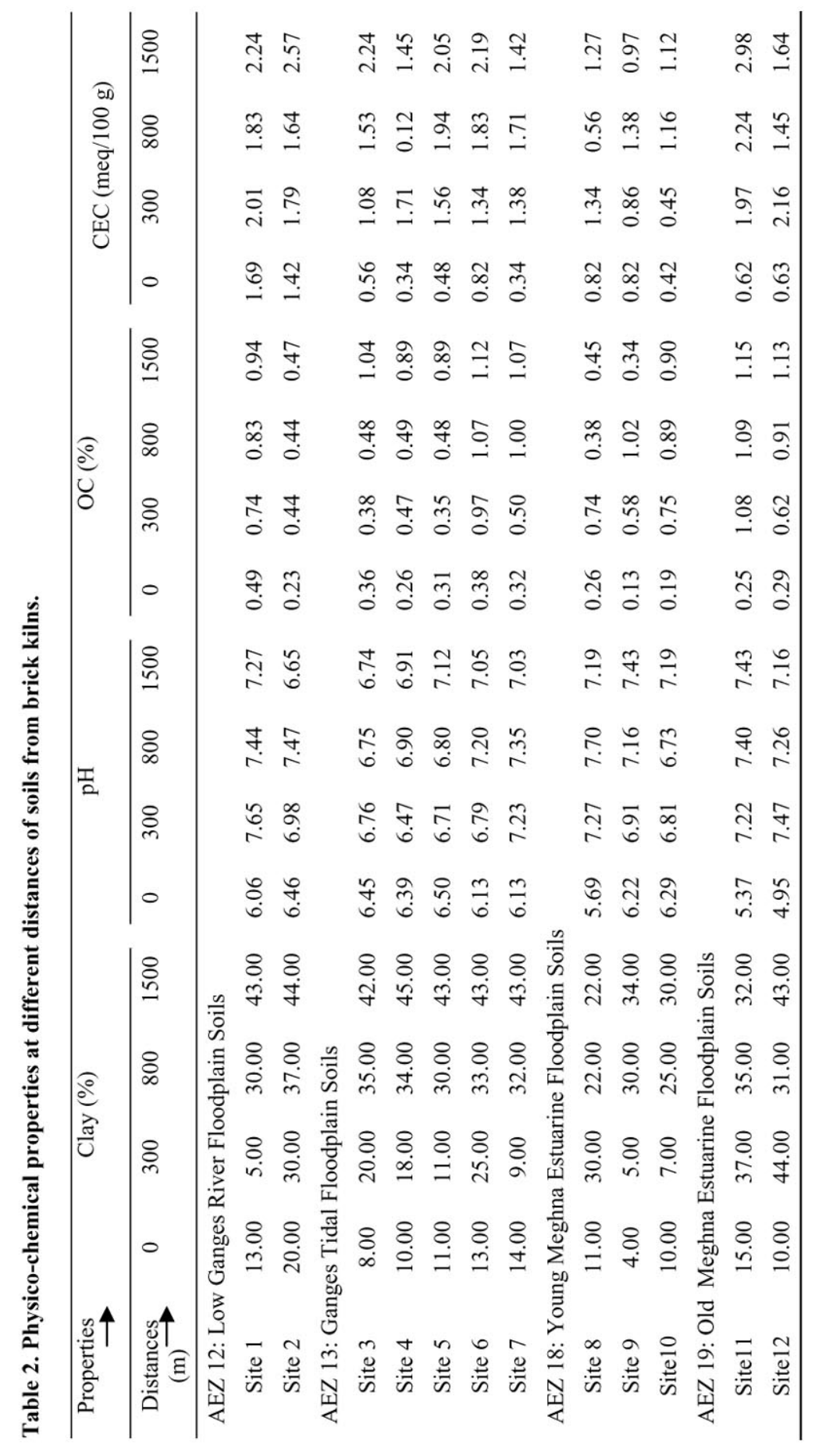


Table 3. Relationship between soil properties and total and available nutrient concentrations.

\begin{tabular}{lllll}
\hline Nutrient & OC & CEC & Clay & $\mathrm{pH}$ \\
\hline Total P & $0.35^{* * *}$ & $0.43 * * *$ & $0.49 * * *$ & $0.23 * * *$ \\
Available P & -0.15 & -0.11 & - & $0.43 * * *$ \\
Total S & $0.53 * * *$ & $0.51 * * *$ & $0.39 * * *$ & $0.39^{* * *}$ \\
Available S & $-0.45^{* * *}$ & $-0.42^{* * *}$ & $-0.43 * * *$ & $-0.41 * * *$ \\
\hline
\end{tabular}

$*, * *$ and $* * *$ indicate significance at 5,1 and $0.1 \%$ level, respectively.
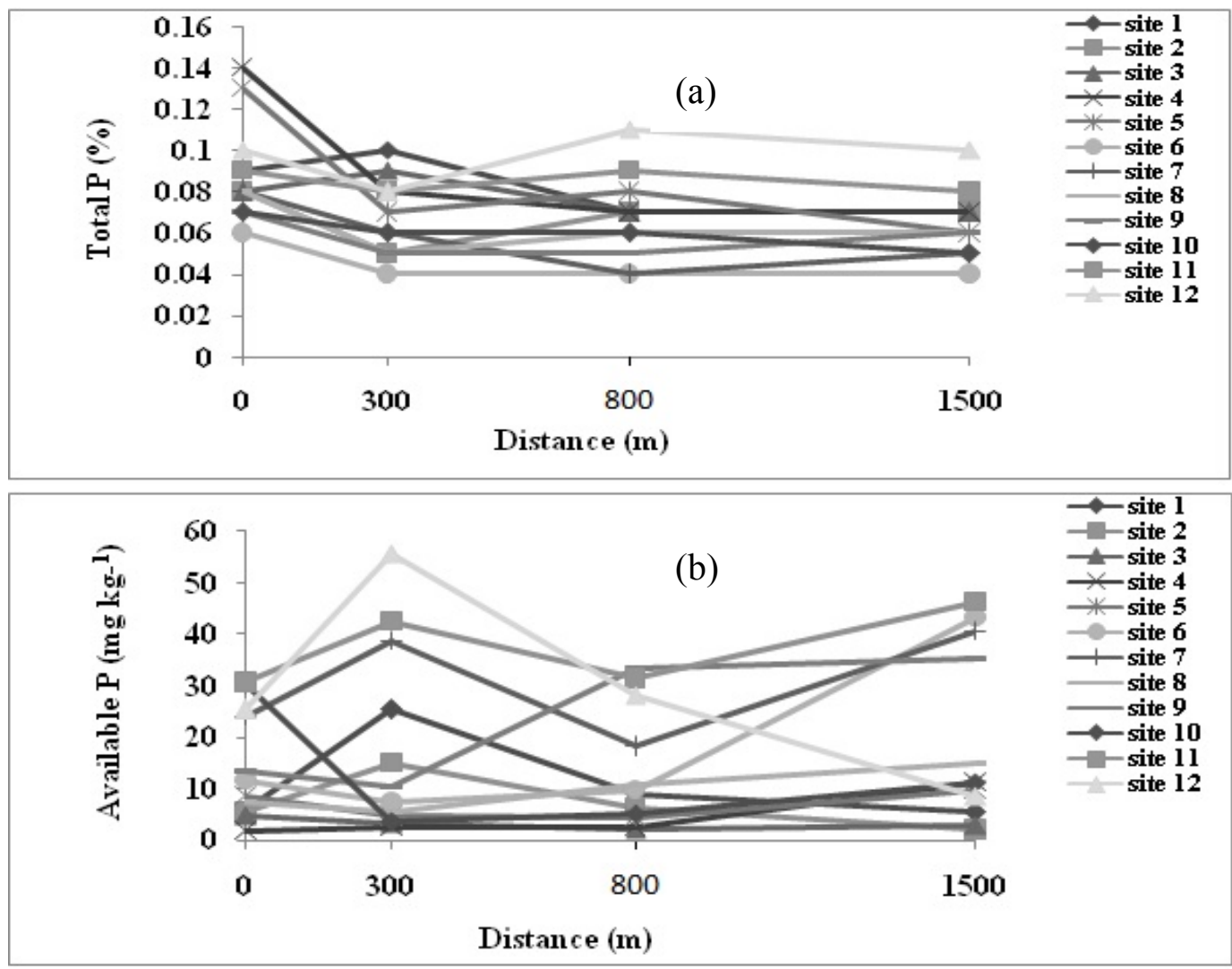

Fig. 1. Concentration of (a) total and (b) available $\mathrm{P}$ at different distances in soil from brick kilns.

The total sulfur was found to lie in the range of 0.11 to $0.30 \%$ (Fig. 2a). Relatively higher total concentration was found in soil away from brick kiln might indicate the greater trapping of atmospheric sulfur. It might be interpreted to mean that due to the high temperature, gases produced from the clement come back from the atmosphere to the earth surface as acid rain and destroy crop production. In case of available $\mathrm{S}$ concentration the sequence use (Fig. $2 \mathrm{~b}$ ): $0 \mathrm{~m}>$ $300 \mathrm{~m}>800 \mathrm{~m}>1500 \mathrm{~m}$. Total $\mathrm{S}$ concentration in soil was significantly correlated with $\mathrm{pH}$, 
organic matter; cation exchange capacity and clay content (Table 3). Available S concentration in soil was negatively correlated with organic matter, cation exchange capacity, clay content and $\mathrm{pH}$. It might be due to the increasing available $\mathrm{S}$ that increased with the decreasing soil $\mathrm{pH}$ (Yaseen et al. 2015, Bisht and Neupane 2015). Plant cultivation is not possible at $0 \mathrm{~m}$. due to extremely high temperature $\left(1550^{\circ} \mathrm{F}\right)$ of adjacent area of brick kiln that make the soil unproductive (Monga et al. 2012).
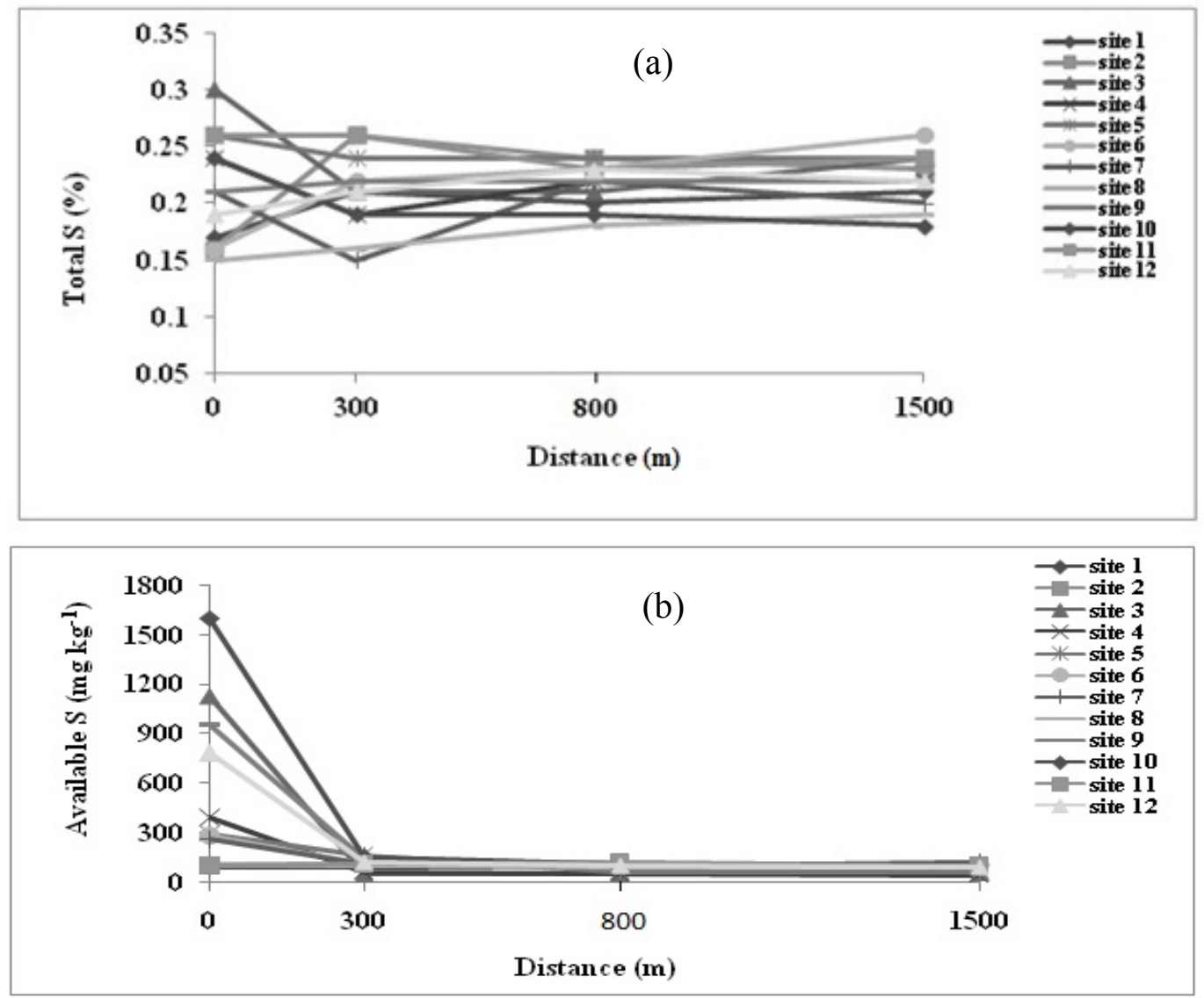

Fig. 2. Concentration of (a) total and (b) available $\mathrm{S}$ at different distances in soils from brick kilns.

Effects of brick making operations on status of phosphorus and sulfur in plant: The results demonstrated that the phosphorus concentration in plant ranges from $19.29 \mathrm{mg} \mathrm{kg}^{-1}$ at $1500 \mathrm{~m}$ in site 4 to $69.15 \mathrm{mg} \mathrm{kg}^{-1}$ at $800 \mathrm{~m}$ in site 12 (Fig. 3). Phosphorus accumulation in plant depends on available $\mathrm{P}$ concentration in soil. Most of the sites showed that the accumulation of $\mathrm{P}$ was higher at $800 \mathrm{~m}$ compared to $300 \mathrm{~m}$. It might be due to highly affected soils $(0 \mathrm{~m}$ and $300 \mathrm{~m})$ often providing little available nutrients like $\mathrm{P}$ for plant growth. Thus, near the brick kilns area the high temperature reduced the availability of $\mathrm{P}$. 


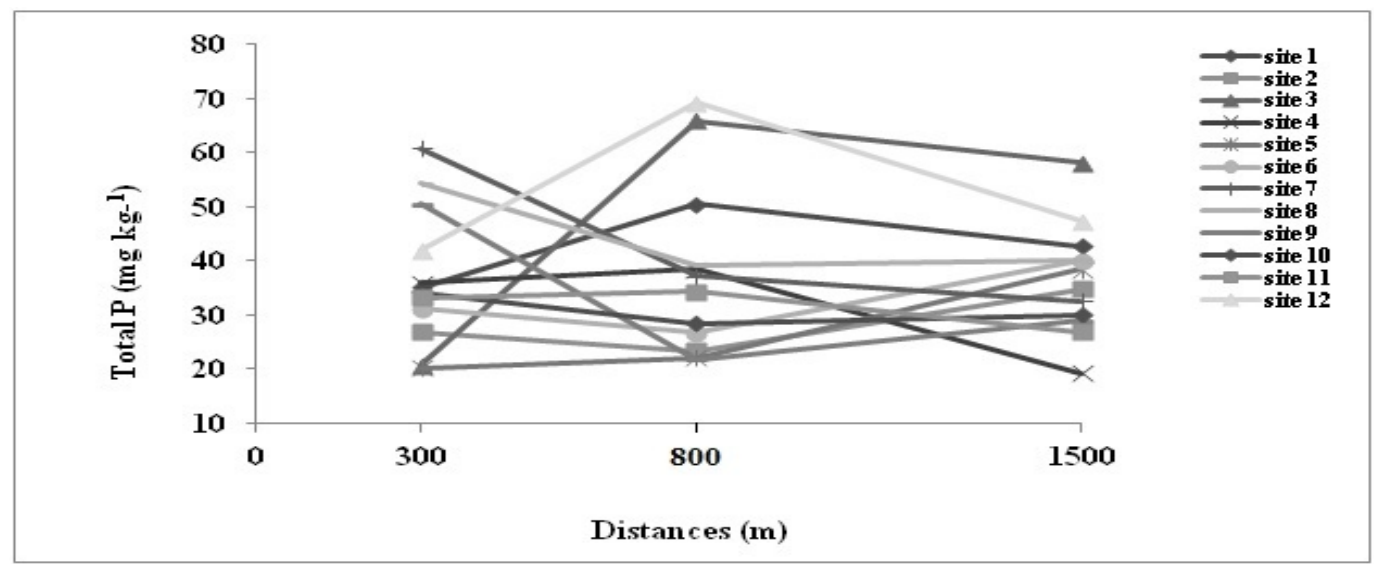

Fig. 3. Concentration of total $\mathrm{P}$ in plant at different distances from brick kilns.

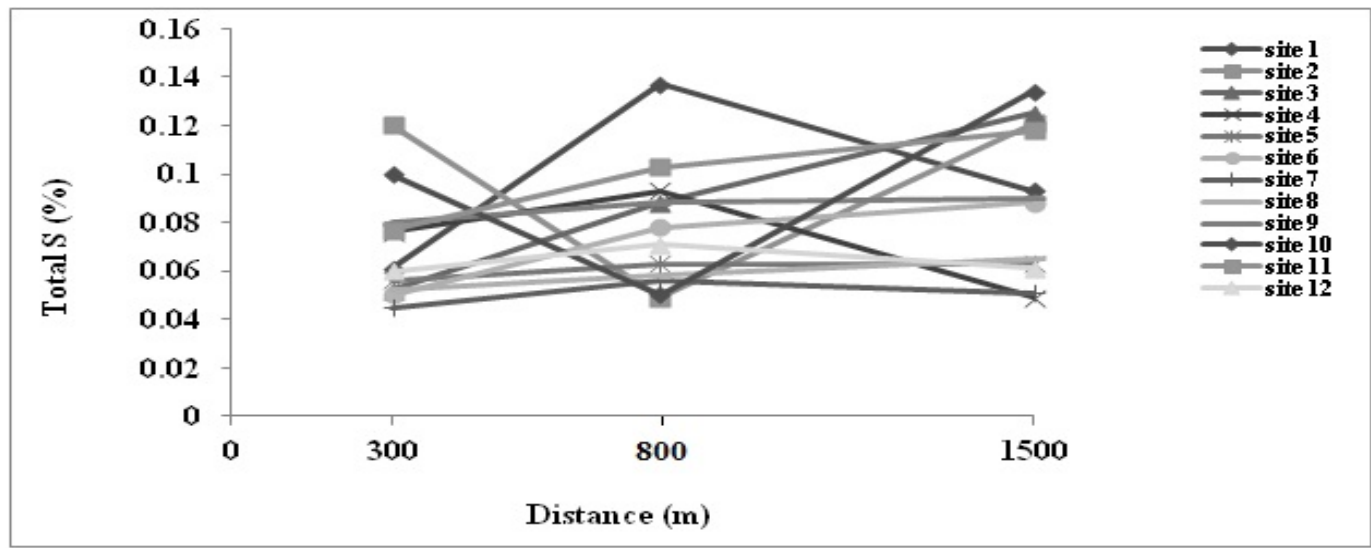

Fig. 4. Concentration of total $\mathrm{S}$ in plant at different distances from brick kilns.

The highest accumulation of $\mathrm{S}$ in plant was $0.14 \%$ at $800 \mathrm{~m}$ (site 11) and the lowest was $0.05 \%$ at $0 \mathrm{~m}$ (site 7, Fig. 4). Results indicated that at $800 \mathrm{~m}$ distances plant accumulate highest amount of $\mathrm{S}$ in most of the sites. And appreciable amount of available $\mathrm{S}$ was found at $0 \mathrm{~m}$ and 300 $\mathrm{m}$ but plant adjacent to the brick kiln cannot uptake this available $\mathrm{S}$ because of high temperature $\left(1550^{\circ} \mathrm{F}\right.$, Monga et al. 2012).

\section{Conclusion}

The total $\mathrm{P}$ concentration and total and available $\mathrm{S}$ concentrations in soil were higher at $0 \mathrm{~m}$ distances compared to $300 \mathrm{~m}, 800 \mathrm{~m}$ and $1500 \mathrm{~m}$ distances around the brick kiln areas. The present research suggested that $800 \mathrm{~m}$ soils near brick kilns provide high P and S uptake by plant. It can be concluded that the findings of the work are alarming for crop production at a distance of $0 \mathrm{~m}$ to $300 \mathrm{~m}$. So, care should be taken properly to protect our land resources from degradation by brick kilns. 


\section{References}

BARC (Bangladesh Agricultural Research Council). 1997. Fertilizer Recommendation Guide. Bangladesh Agricultural Research Council, BARC publications. Farmgate, Dhaka. Bangladesh. pp. 196.

Bayron, R. K. 2009. Brick kilns going green. The Daily Star. December 13, 2009.

Bisht, G. and S. Neupane. 2015. Impact of brick kilns emission on soil quality of agriculture fields in the vicinity of selected Bhaktapur area of Nepal. J. Appl. Env. Soil. Sci. 1: 1-8.

Chapman, H. D. 1965. Cation-exchange capacity. In: C.A. Black (ed.). Methods of soil analysis - Chemical and microbiological properties. Agronomy 9: 891-901.

Jackson, M. L. 1962. Soil Chemical Analysis. New York, Prentice-Hall Inc. pp. 498.

Jackson, M. L. 1973. Soil Chemical Analysis. 1st ed. Prentice-Hall Inc. Englewood Cliffs. NJ.

Kabata, A. and H. Pendias. 1992. Trace Elements in Soils and Plants. 2nd ed., CRC press, London. pp. 24115.

Kabata-Pendias, A. and H. Pendias. 2001. Trace elements in soils and plants. 3rd ed., CRC press, Boca Raton, FL. pp. 260-267.

Monga, V., L. P. Singh, A. Bhardwaj and H. Singh. 2012. Respiratory health in brick kiln workers. Int. J. Phy. Soci. Sci. 2(4): 2249-5894.

Piper, C. S. 1950. Soil and Plant Analysis. The University of Adelaide Press. Adelaide. Australia. pp. 368.

Rahman, M. K., M. Eunuch, G. M. F. Haque, H. R. Khan and A. J. M. A. Rouf. 2015. Nutrient losses of agricultural land due to brick manufacturing in the central region of Bangladesh. J. Biol. Sci. 24(1): 5357.

Sikder, A. H. F, S. Khanom, M. D. H. Molla, M. F. Hossain and Z. Parveen. 2015. Lead and cadmium accumulation in nearby brick kiln agro-environmental ecosystems. Dhaka University J. Biol. Sci. 25(1): 75-81.

Sikder, A. H. F, S. Khanom, M. F. Hossain and Z. Parveen. 2016. Accumulation of Zn, Cu, Fr, Mn and Pb due to brick manufacturing in agricultural soils and plants. B. J. Sci. Res. 28(1): 51-59.

USEPA (United State Environmental Protection Agency). 1986. Compilation of Air Pollutant Emission Factors, U. S. Environmental Protection Agency, Research Triangle Park, NC, October 1986.

Yaseen, S., A. Pal, S. Singh and B. M. Skinder. 2015. Soil quality of agricultural fields in the vicinity of selected mining areas of Raniganj Coalfield India. J. Env. Analyt. Toxico. 5(3): 269-275.

(Manuscript received on 26 June, 2016; revised on 1 January, 2017) 